\title{
Hubungan Pengetahuan, Sikap, dan Tindakan terhadap DBD dengan Keberadaan Jentik di Lingkungan Rumah Masyarakat Kecamatan Medan Marelan Tahun 2018
}

\section{Community Behaviour on DHF in Relationship With Mosquito Larvae Presence in Marelan District Area of Medan in 2018}

\author{
Ade Pryta Simaremare*, Novita Hasiani Simanjuntak, dan Saharnauli J. V. Simorangkir \\ Fakultas Kedokteran, Universitas HKBP Nommensen \\ Jl. Sutomo No. 4 Medan, 20234, Sumatera Utara, Indonesia
}

\section{INFO ARTIKEL}

Article History:

Received: 10 Apr. 2019

Revised: 14 Okt. 2019

Accepted: 14 Okt. 2019

Kontribusi:

Ade Pryta Simaremare sebagai Kontributor Utama dalam artikel ini.

Keywords:

Dengue Hemorrhagic Fever mosquito larvae community behaviour

Kata kunci:

DBD

Jentik nyamuk

Perilaku masyarakat

\section{A B S T RA C T / A B S T R A K}

Dengue Hemorrhagic Fever (DHF) is public health problem in Indonesia and causes extraordinary event with high mortality rate. It is caused by Dengue virus infection of the genus Flavivirirus transmitted by Aedes aegypti bite. All regions in Indonesia are risky for contracting DHF because the virus and the mosquitoes have spread widely in residential housing and public places throughout Indonesia. This study used an observational analytic design with cross sectional study. The respondents were people in the Marelan District of Medan. Data on knowledge, attitudes and practices about DHF were obtained through a guided questionnaire. Data about the presence of Aedes aegypti larvae were obtained through direct observation of the environment around the respondent's houses. The chi square analysis showed that the level of knowledge about DHF was not related to the presence of larvae with a $p$ value of 0.128 ( $p$ value> 0.05 ). For attitude and practice aspects indicate relationship with $p$ values of 0.01 and 0.004 ( $p$ value< 0.05 ). Often the knowledge about DHF is not manifested as action to reduce the presence of mosquito larvae causing the disease in their environment. Still, guidance in intensive counseling and motivating the community about eradicating mosquito nests is very important.

Demam Berdarah Dengue (DBD) merupakan masalah kesehatan masyarakat di Indonesia dan sering menimbulkan kejadian luar biasa dengan tingkat kematian yang tinggi. Penyakit ini disebabkan oleh infeksi virus Dengue dari genus Flavivirus yang dapat masuk ke dalam tubuh manusia melalui perantaraan nyamuk Aedes aegypti. Seluruh wilayah di Indonesia berisiko terjangkit penyakit DBD, sebab baik virus penyebab maupun nyamuk penularnya sudah tersebar luas di perumahan penduduk maupun di tempat-tempat umum di seluruh Indonesia. Penelitian ini menggunakan disain penelitian analitik observasional dengan metode cross sectional. Responden dalam penelitian ini adalah masyarakat di Kecamatan Medan Marelan. Data variabel pengetahuan, sikap dan tindakan mengenai DBD diperoleh melalui kuesioner secara terpimpin. Data variabel keberadaan jentik nyamuk Aedes aegypti diperoleh melalui observasi secara langsung lingkungan sekitar rumah responden. Hasil analisis chi square menunjukkan bahwa tingkat pengetahuan mengenai penyakit DBD tidak berhubungan dengan keberadaan jentik dengan nilai $\mathrm{p}=0,128$ ( $p$ value $>0,05$ ). Untuk aspek sikap dan tindakan menunjukkan adanya hubungan dengan nilai $\mathrm{p}$ masingmasing 0,01 dan 0,004 ( $p$ value $<0,05$ ). Seringkali pengetahuan mengenai DBD tidak diwujudnyatakan menjadi suatu tindakan untuk mengurangi keberadaan jentik nyamuk penyebab penyakit tersebut di lingkungan rumahnya. Walaupun demikian, pembinaan dalam penyuluhan dan motivasi yang intensif kepada masyarakat tentang pemberantasan sarang nyamuk tetap sangat penting dilakukan.

(C) 2020 Jurnal Vektor Penyakit. All rights reserved

\section{PENDAHULUAN}

Demam Berdarah Dengue (DBD) merupakan salah satu penyakit yang menimbulkan masalah kesehatan masyarakat di Indonesia dan sering menimbulkan suatu kejadian luar biasa dengan tingkat kematian yang tinggi. Penanggulangan penyakit ini mengalami masalah yang cukup kompleks karena penyakit ini belum ditemukan obatnya. $^{1}$ 
Penyakit Demam Berdarah Dengue dapat menyerang semua golongan umur. Sejak tahun 1968 hingga tahun 2009, World Health Organization (WHO) mencatat negara Indonesia sebagai negara dengan kasus DBD tertinggi di Asia Tenggara. Di Indonesia, DBD pertama kali ditemukan di kota Surabaya pada tahun 1968, sebanyak 58 orang terinfeksi dan 24 orang meninggal dunia. Sejak saat itu, penyakit ini menyebar luas ke seluruh Indonesia. Jumlah kasus DBD fluktuatif setiap tahunnya. Data dari Direktorat Pencegahan dan Pengendalian Penyakit Tular Vektor dan Zoonotik, Kemenkes RI, pada tahun 2014 jumlah penderita mencapai 100,347 dan 907 orang diantaranya meninggal. Pada tahun 2015, sebanyak 129,650 penderita dan 1,071 kematian. Kemudian pada tahun 2016 sebanyak 202,314 penderita dan 1,593 kematian dan pada tahun 2017, terhitung sejak Januari hingga Mei tercatat sebanyak 17.877 kasus, dengan 115 kematian. Angka kesakitan atau Incidence Rate (IR) di 34 provinsi di 2015 mencapai 50.75 per 100 ribu penduduk, dan IR di 2016 mencapai 78.85 per 100 ribu penduduk. Angka ini masih lebih tinggi dari target IR nasional yaitu 49 per 100 ribu penduduk.

Demam Berdarah Dengue (DBD) disebabkan oleh infeksi virus Dengue dari genus Flavivirus, famili Flaviviridae yang terdiri atas 4 serotipe. Virus ini dapat masuk ke dalam tubuh manusia melalui perantaraan nyamuk Aedes aegypti dan Aedes albopictus. Kedua jenis nyamuk ini terdapat hampir di seluruh pelosok Indonesia, kecuali di tempattempat ketinggian lebih dari 1000 meter di atas permukaan laut. Seluruh wilayah di Indonesia mempunyai risiko untuk terjangkit penyakit demam berdarah dengue, sebab baik virus penyebab maupun nyamuk penularnya sudah tersebar luas di perumahan penduduk maupun di tempat-tempat umum diseluruh Indonesia., ${ }^{3,4}$

Cara paling baik untuk mencegah penyakit ini adalah dengan tindakan pemberantasan jentik nyamuk penularnya yang dikenal dengan Pemberantasan Sarang Nyamuk Demam Berdarah Dengue (PSNDBD). Keberadaan jentik yang digambarkan dengan angka bebas jentik lebih besar atau sama dengan 95\% diharapkan penularan DBD dapat dicegah atau dikurangi. ${ }^{5}$ Hal-hal yang menyebabkan tingginya angka kejadian DBD disebabkan oleh banyaknya tempat perkembangbiakan nyamuk yang bisa berupa bak mandi, ember, gentong, TPA yang bukan untuk keperluan sehari-hari seperti vas bunga, ban bekas, botol bekas, dan tempat sampah, TPA alamiah seperti lubang pohon, pelepah daun, dan lubang batu. ${ }^{1}$

Unsur perilaku masyarakat berupa pengetahuan, sikap, dan tindakan yang diwujudnyatakan dalam kegiatan pemberantasan sarang nyamuk (PSN) seperti menutup, menguras, dan mengubur belum teridentifikasi dengan jelas apakah berhubungan secara langsung dengan keberadaan jentik nyamuk penular DBD. Penelitian yang dilakukan oleh Nugrahaningsih dkk, menunjukkan bahwa pengetahuan responden tidak berhubungan dengan keberadaan jentik nyamuk penular DBD di daerah kerja Puskesmas Kuta Utara, namun aspek sikap dan tindakan berhubungan dengan keberadaan jentik nyamuk di daerah tersebut. Hasil yang berbeda ditunjukkan oleh penelitian oleh Suyasa $\mathrm{dkk}^{7}$, yang menyatakan tidak ada hubungan antara pengetahuan dan sikap dengan keberadaan vektor DBD di wilayah kerja Puskesmas I Denpasar Selatan. Hal ini menunjukkan bahwa perilaku masyarakat masih berbeda-beda dalam hubungannya dengan keberadaan jentik nyamuk penular DBD.

Dinas Kesehatan Kota Medan telah melakukan berbagai upaya penanggulangan DBD, namun jumlah kasus DBD khususnya di Kecamatan Medan Marelan masih cukup tinggi. ${ }^{8}$ Unsur perilaku masyarakat yang berhubungan dengan pengetahuan, sikap, maupun tindakan yang diwujudkan dalam kegiatan pemberantasan sarang nyamuk belum pernah diidentifikasi di daerah kecamatan tersebut. Oleh karena itu, penelitian ini dilakukan untuk mengetahui hubungan perilaku terhadap DBD dengan keberadaan jentik di lingkungan rumah masyarakat Kecamatan Medan Marelan tahun 2018.

\section{METODE}

Penelitian ini menggunakan jenis penelitian observasional analitik dengan 
disain cross sectional. Pengambilan data dilakukan dengan metode rapid survey, karena waktu yang terbatas dengan cakupan area yang luas. Pendekatan pemilihan wilayah dilakukan dengan menggunakan prinsip Probability Proportionate to size berdasarkan jumlah penduduk, sementara sampel rumah tangga diperoleh dengan metode acak sederhana (simple random sampling) dengan minimal besar sampel tujuh responden dari 30 cluster, sehingga total minimal besar sampel adalah 210 responden. Kecamatan Medan Marelan terdiri atas lima Kelurahan yang dibagi dalam beberapa cluster berdasarkan luas wilayah dan jumlah penduduk yaitu Kelurahan Tanah EnamRatus dibagi atas enam cluster, Kelurahan Paya Pasir dibagi atas lima cluster, Kelurahan Rengas Pulau dibagi atas 11 cluster, Kelurahan Labuhan Deli dibagi atas empat cluster, Kelurahan Terjun dibagi atas tujuh cluster, totalnya ada 33 cluster. Dari masing-masing cluster didapatkan 7-8 responden sehingga didapatkan jumlah sampel pada penelitian ini adalah sebanyak 249 responden.

Data variabel pengetahuan, sikap dan tindakan mengenai DBD diperoleh melalui kuesioner yang ditanyakan kepada responden secara terstruktur. Data variabel keberadaan jentik nyamuk vektor DBD diperoleh melalui observasi secara langsung lingkungan sekitar rumah responden. Analisis data pada penelitian ini dilakukan dengan analisis univariat dan bivariat. Analisis univariat bertujuan untuk menjelaskan distribusi frekuensi dari masing-masing variabel yang

Tabel 1. Distribusi Frekuensi Karakteristik Masyarakat Kecamatan Medan Marelan Tahun 2018

\begin{tabular}{llcc}
\hline \multicolumn{1}{c}{ Faktor } & Keterangan & $\begin{array}{c}\text { Frekuensi } \\
\text { (n) }\end{array}$ & \% \\
\hline \multirow{3}{*}{ Usia } & < 35 Tahun & 73 & 29.3 \\
& $\geq$ 35 Tahun & 176 & 70.7 \\
Jenis & Perempuan & 224 & 90.0 \\
Kelamin & Laki-laki & 25 & 10.0 \\
& & & \\
Pekerjaan & Tidak Bekerja & 127 & 51.0 \\
& Bekerja & 122 & 49.0 \\
& & & \\
Pendidikan & $<$ SMA/ sederajat & 150 & 60.2 \\
& $\geq$ SMA/ sederajat & 99 & 39.8 \\
\hline
\end{tabular}

diteliti, yaitu variabel umur, pendidikan, pekerjaan, pengetahuan, sikap dan tindakan mengenai DBD. Analisis bivariat bertujuan untuk mengetahui hubungan antara variabel bebas dengan variabel terikat. Analisis bivariat menggunakan uji Chi Square. Penelitian ini telah mendapatkan persetujuan dari Komisi Etik Penelitian Kesehatan, Fakultas Kedokteran Universitas HKBP Nommensen, nomor: 066/KEPKIFKIXI/2018.

\section{HASIL}

\section{Gambaran Karakteristik Masyarakat Di Kecamatan Medan Marelan Tahun 2018}

Karakteristik masyarakat di Kecamatan Medan Marelan berdasarkan usia, jenis kelamin, pekerjaan, dan tingkat pendidikan dapat diamati pada Tabel 1. Dari tabel terlihat bahwa data pada penelitian ini diperoleh dari penduduk dengan mayoritas berusia di atas 35 tahun $(70,7 \%)$, jenis kelamin perempuan (90\%), tidak bekerja atau bekerja sebagai ibu rumah tangga (51\%), dengan tingkat pendidikan di bawah Sekolah Menengah Atas (SMA) atau sederajat $(60,2 \%)$.

Gambaran Pengetahuan, Sikap, Dan Tindakan Masyarakat Mengenai DBD Di Kecamatan Medan Marelan Tahun 2018.

Tabel 2 berikut menunjukkan distribusi frekuensi tingkat pengetahuan, sikap, dan tindakan masyarakat di Kecamatan Medan Marelan mengenai penyakit demam berdarah dengue. Dapat diamati bahwa hampir setengah dari jumlah responden memiliki tingkat pengetahuan yang baik, namun memiliki sikap yang kurang yaitu dengan

Tabel2. Distribusi Frekuensi Pengetahuan, Sikap, Dan Tindakan Masyarakat Mengenai DBD di Kecamatan Medan Marelan Tahun 2018

\begin{tabular}{llcc}
\hline \multicolumn{1}{c}{$\begin{array}{c}\text { Aspek } \\
\text { Perilaku }\end{array}$} & Keterangan & $\begin{array}{c}\text { Frekuensi } \\
\text { (n) }\end{array}$ & \% \\
\hline \multirow{3}{*}{ Pengetahuan } & Kurang & 121 & 48.6 \\
& Baik & 128 & 51.4 \\
& & & \\
Sikap & Kurang & 128 & 51.4 \\
& Baik & 121 & 48.6 \\
\multirow{2}{*}{ Tindakan } & Kurang & 88 & 35.3 \\
& Baik & 161 & 64.7 \\
\hline
\end{tabular}


persentase masing-masing sebesar 51,4\%. Sedangkan untuk tindakan pencegahan penyakit DBD tersebut, mayoritas responden berada pada kategori baik yaitu sebesar $64,7 \%$.

Tabel 3 menunjukkan distribusi frekuensi tingkat pengetahuan, sikap, dan tindakan mengenai DBD berdasarkan karakteristik masyarakat di Kecamatan Medan Marelan. Pada karakteristik usia pengetahuan dan sikap frekuensinya tidak berbeda signifikan, namun tindakan mayoritas menunjukkan frekuensi yang baik pada usia kurang maupun lebih dari 35 tahun. Hal yang sama juga ditunjukkan pada karakteristik jenis kelamin. Pada responden yang tidak bekerja, frekuensi pengetahuan dan sikap yang buruk lebih tinggi namun frekuensinya lebih tinggi untuk tindakan yang baik. Frekuensi responden dengan tingkat pendidikan di bawah SMA memiliki sikap yang buruk, namun tingkat pengetahuan dan tindakannya mayoritas baik.

Gambaran Keberadaan Jentik Nyamuk Aedes aegypti Di Lingkungan Rumah Masyarakat Medan Marelan Tahun 2018.

Keberadaan jentik nyamuk Aedes aegypti di lingkungan rumah masyarakat Medan Marelan pada Tabel 4 menunjukkan bahwa sebanyak 64,3\% rumah responden yang diobservasi menunjukkan tidak adanya jentik-jentik nyamuk penyebab DBD di sekitar rumahnya.

Tabel3. Distribusi Frekuensi Pengetahuan, Sikap, dan Tindakan Mengenai DBD Berdasarkan Karakteristik Masyarakat di Kecamatan Medan Marelan Tahun 2018

\begin{tabular}{|c|c|c|c|c|c|c|c|}
\hline \multirow{2}{*}{ Faktor } & \multirow{2}{*}{ Keterangan } & \multicolumn{2}{|c|}{ Pengetahuan } & \multicolumn{2}{|c|}{ Sikap } & \multicolumn{2}{|c|}{ Tindakan } \\
\hline & & Kurang & Baik & Buruk & Baik & Buruk & Baik \\
\hline \multirow{2}{*}{ Usia } & $<35$ Tahun & 35 & 38 & 40 & 33 & 26 & 47 \\
\hline & $\geq 35$ Tahun & 86 & 90 & 88 & 88 & 62 & 114 \\
\hline Jenis & Perempuan & 109 & 115 & 117 & 107 & 82 & 142 \\
\hline Kelamin & Laki -laki & 12 & 13 & 11 & 14 & 6 & 9 \\
\hline \multirow{2}{*}{ Pekerjaan } & Tidak Bekerja & 65 & 62 & 70 & 57 & 50 & 77 \\
\hline & Bekerja & 56 & 66 & 58 & 64 & 38 & 84 \\
\hline \multirow{2}{*}{ Pendidikan } & $<$ SMA/ sederajat & 68 & 82 & 81 & 69 & 57 & 93 \\
\hline & $\geq$ SMA/ sederajat & 53 & 46 & 47 & 52 & 31 & 68 \\
\hline
\end{tabular}

Hubungan Pengetahuan, Sikap, Dan Tindakan Masyarakat Mengenai DBD dengan Keberadaan Jentik Di Kecamatan Medan Marelan Tahun 2018.

Tabel 5 menunjukkan bahwa tingkat pengetahuan mengenai DBD tidak berhubungan dengan keberadaan jentik dengan nilai-p 0,128 ( $p$ value $>0,05$ ). Untuk aspek sikap dan tindakan menunjukkan adanya hubungan dengan nilai-p masingmasing 0,01 dan 0,004 ( $p$ value $<0,05$ ).
Tabel 4. Distribusi Frekuensi Keberadaan Jentik Nyamuk Aedes aegypti di Lingkungan Rumah Masyarakat Medan Marelan Tahun 2018

\begin{tabular}{lcc}
\hline \multicolumn{1}{c}{ Keterangan } & Jumlah & \% \\
\hline Positif & 89 & 35.7 \\
Negatif & 160 & 64.3 \\
\hline
\end{tabular}




\section{PEMBAHASAN}

Responden pada penelitian ini mayoritas berusia di atas 35 tahun dan berjenis kelamin perempuan. Perempuan pada umumnya lebih mudah untuk menerima informasi dan memiliki keinginan untuk mengusahakan kesehatan terutama bagi keluarganya. Selain itu, usia mayoritas di atas 35 tahun juga sudah cukup matang untuk memikirkan hal yang baik bagi diri sendiri dan keluarganya. Untuk pekerjaan, responden menunjukkan hasil yang kurang lebih sama yaitu tidak bekerja dan bekerja. Bekerja dalam kuesioner yang diberikan dapat menunjukkan pekerjaan responden sebagai petani/ nelayan atau penjual produk pertanian/ perikanan, pekerja kantoran, maupun pekerjaan lainnya. Hal ini mempengaruhi ketersediaan waktu responden untuk perilaku pemberantasan sarang nyamuk di lingkungan rumahnya. Tingkat pendidikan juga akan

Tabel 3. Hubungan Pengetahuan, Sikap, Dan Tindakan Masyarakat Mengenai DBD dengan Keberadaan Jentik di Kecamatan Medan Marelan Tahun 2018

\begin{tabular}{|c|c|c|c|c|c|}
\hline \multirow{2}{*}{ Aspek Perilaku } & & \multicolumn{2}{|c|}{ KeberadaanJentik } & \multirow{2}{*}{ Total } & \multirow{2}{*}{$\boldsymbol{P}$} \\
\hline & & Positif & Negatif & & \\
\hline \multirow{3}{*}{ Pengetahuan } & Kurang & 49 & 72 & 121 & \multirow{3}{*}{0.128} \\
\hline & Baik & 40 & 88 & 128 & \\
\hline & Total & 89 & 160 & 249 & \\
\hline \multirow{2}{*}{ Sikap } & Kurang & 36 & 92 & 128 & \multirow{3}{*}{0.010} \\
\hline & Baik & 53 & 68 & 121 & \\
\hline \multirow{4}{*}{ Tindakan } & Total & 89 & 160 & 249 & \\
\hline & Kurang & 21 & 67 & 88 & \multirow{3}{*}{0.004} \\
\hline & Baik & 68 & 93 & 161 & \\
\hline & Total & 89 & 160 & 249 & \\
\hline
\end{tabular}

mempengaruhi mudah tidaknya seseorang menerima informasi maupun dalam memutuskan apa yang perlu dilakukan dalam menyelesaikan suatu masalah, dalam hal ini isu DBD. Masyarakat yang memiliki tingkat pendidikan tinggi akan lebih berorientasi pada tindakan preventif, mengetahui lebih banyak tentang masalah kesehatan dan memiliki status kesehatan yang lebih baik. ${ }^{6}$

Pemerintah telah melakukan berbagai upaya untuk penanggulangan DBD, namun kasus DBD masih cukup tinggi di berbagai daerah khususnya di Kecamatan Medan Marelan. Pencegahan dan pemberantasan penyakit DBD yang optimal tidak dapat dicapai tanpa kerja sama dan keterlibatan masyarakat pada setiap kampanye pencegahan dan penanggulangan DBD. Setiap program kampanye pemberantasan DBD akan dapat berhasil bila masyarakat memahami manfaat program pencegahan yang harus dilaksanakan.

Pengetahuan dan sikap responden masih jauh dari optimal, walaupun dalam tindakan mayoritas sudah baik. Kurangnya pengetahuan disebabkan oleh masyarakat yang belum memiliki pemahaman yang benar tentang pencegahan dan pengendalian vektor DBD. ${ }^{10}$ Sebagian masyarakat mengetahui tentang DBD dari banyaknya informasi yang beredar di media massa seperti televisi maupun media sosial yang seringkali diterima begitu saja tanpa konfirmasi yang benar dari pihak yang lebih memahami masalah DBD tersebut. Oleh karena itu, masyarakat yang memiliki pengetahuan yang buruk masih 
tergolong tinggi pada penelitian ini. Sikap seseorang mengenai DBD dipengaruhi oleh pengetahuannya mengenai DBD. Pengetahuan dan pemahaman masyarakat yang masih kurang mengenai DBD juga mempengaruhi bagaimana masyarakat tersebut bersikap untuk pencegahan terjadinya DBD. Tindakan responden masyarakat terhadap penyakit DBD mayoritas sudah baik $(64,7 \%)$, namun hal ini belum optimal karena masih banyak responden yang memiliki pengetahuan kurang $(35,3 \%)$. Hal ini disebabkan oleh karena pengetahuan dan sikap yang masih tergolong kurang baik.

Banyak faktor yang mempengaruhi kejadian DBD. Kepadatan jentik nyamuk juga merupakan faktor yang penting dalam penularan DBD, seperti penelitian yang dilakukan di daerah endemis DBD di Jawa Timur. ${ }^{11}$ Pada penelitian yang dilakukan oleh Herlina Susmaneli diperoleh hasil bahwa beberapa variabel yang berhubungan bermakna dengan kejadian DBD di Rokan Hulu adalah tempat penampungan air, ketersediaan tutup penampung air, dan frekuensi pengurasan penampung air. ${ }^{12}$

Pada penelitian ini, lingkungan rumah mayoritas responden $(64,3 \%)$ tidak menunjukkan adanya jentik nyamuk Aedes aegypti oleh karena penelitian dilakukan pada musim kemarau sehingga tidak banyak terbentuk genangan air sebagai tempat persemaian jentik tersebut. ${ }^{13,14}$ Penelitian ini menunjukkan $35,7 \%$ responden yang di lingkungan rumahnya terdapat jentik. Jentikjentik tersebut kemungkinan besar terdapat pada tempat-tempat yang memungkinkan terdapatnya genangan air di dalam rumah seperti pot bunga atau tempat penampungan air bersih, misalnya ember atau gentong, yang tidak ditutup.

Kontainer yang tidak ditutup dan tidak dibersihkan atau diganti airnya secara teratur akan menjadi tempat persemaian yang baik bagi jentik nyamuk Aedes aegypti. Hal ini sesuai dengan penelitian yang dilakukan oleh Ririh dan Anny yang mendukung penelitian yang dilakukan oleh Yuwono. ${ }^{14}$ Penelitian ini menunjukkan bahwa tempat yang paling banyak ditemukan jentik nyamuk penyebab penyakit DBD tersebut paling banyak ditemukan pada tempat penampungan air untuk keperluan sehari-hari seperti drum, tempayan, bak mandi, bak WC, ember, dan sebagainya.

Penelitian yang dilakukan oleh Mardiyani menunjukkan bahwa keberadaan jentik nyamuk dipengaruhi oleh kelembaban udara, keberadaan saluran air hujan yang tidak lancar, dan keberadaan kontainer. ${ }^{15}$ Kelembaban udara pada kisaran 70-80 persen merupakan kondisi yang optimal untuk proses embroisasi dan ketahanan hidup jentik nyamuk. Perubahan cuaca dari musim kemarau ke musim penghujan juga mempengaruhi keberadaan jentik nyamuk tersebut oleh karena semakin besarnya kemungkinan untuk terdapat genangan air hujan di kontainer-kontainer yang tidak tertutup sebagai tempat persemaian jentikjentik nyamuk tersebut. Jentik-jentik tersebut bisa berada pada tempat-tempat yang memungkinkan terdapatnya genangan air seperti pot bunga, botol minuman bekas, ban bekas, talang, dan lain-lain.

Pada penelitian ini tidak tampak perbedaan yang signifikan dalam perbandingan keberadaan jentik nyamuk Aedes aegypti pada responden yang pengetahuannya baik terhadap yang pengetahuannya kurang yaitu 40 responden dibandingkan dengan 49 responden. Responden yang di lingkungannya tidak ditemukan jentik nyamuk pada yang pengetahuannya baik dibandingkan dengan yang pengetahuannya kurang juga tidak menunjukkan perbedaan yang signifikan. Hal ini sesuai dengan hasil uji chi square dengan nilai $\mathrm{p}=0,128$ ( $p$ value $>0,05)$ sehingga tidak ada hubungan yang signifikan antara pengetahuan responden tentang penyakit DBD dengan keberadaan jentik nyamuk penyebab penyakit tersebut di lingkungan rumahnya.

Penelitian yang dilakukan oleh Gede Suyasa, dan Aryani dkk, ${ }^{16}$ juga menunjukkan tidak adanya hubungan antara tingkat pengetahuan responden dengan keberadaan jentik nyamuk vektor penyebab DBD tersebut. Sebagian besar responden memiliki pengetahuan yang diperoleh dari televisi, media cetak, maupun brosur dan penyuluhan yang dilakukan oleh petugas kesehatan. Namun, pengetahuan tersebut tidak diwujudnyatakan menjadi suatu tindakan 
untuk mengurangi keberadaan jentik nyamuk penyebab penyakit tersebut di lingkungan rumahnya. Hal ini yang menyebabkan masih adanya ditemukan jentik nyamuk di lingkungan rumah responden.

Sikap responden yang kurang mengenai penyakit DBD memberikan dampak masih banyaknya ditemukan jentik nyamuk Aedes aegypti di lingkungan rumahnya, sedangkan responden yang sikapnya sudah baik juga ditemukan adanya jentik, namun menunjukkan jumlah yang cukup signifikan dalam hal jumlah respondennya $(71,87 \%$ banding $56,19 \%)$. Hal ini ditunjukkan oleh uji analisis chi square yang menunjukkan adanya hubungan yang signifikan antara sikap responden tentang penyakit DBD dengan keberadaan jentik nyamuk Aedes aegypti tersebut dengan nilai $\mathrm{p}=0,01$ ( $p$ value $>0,05)$.

Penelitian ini juga menunjukkan adanya hubungan yang signifikan antara tindakan perihal DBD dengan keberadaan jentik nyamuk tersebut. Masih terdapatnya jentik nyamuk penular DBD di Kecamatan Medan Marelan (35.7\%) menunjukkan bahwa pelaksanaan pemberantasan sarang nyamuk oleh responden tersebut belum optimal. Hal ini dapat diketahui dari hasil penelitian yang menunjukkan bahwa walaupun sikap dan tindakan mayoritas responden sudah baik namun keberadaan jentik nyamuk tersebut masih cukup tinggi di lingkungan rumah Kecamatan Medan Marelan. Hal ini menunjukkan masyarakat masih kurang dalam kesadaran perilaku yang mandiri dan teratur dalam menguras bak mandi dan menutup tempat penampungan air maupun mengubur benda-benda yang potensial untuk tempat perkembangbiakan nyamuk Aedes aegypti. Perilaku ini yang berhubungan secara langsung dengan keberadaan jentik nyamuk tersebut yang akan berkembang menjadi nyamuk dewasa sehingga rantai penularan penyakit DBD dapat diputuskan. ${ }^{17}$

\section{KESIMPULAN}

Berdasarkan hasil penelitian ini dapat diambil kesimpulan bahwa pengetahuan dan sikap responden penelitian ini mengenai DBD tidak konsisten dengan tindakan yang dilakukan dalam pemberantasan sarang nyamuk. Pengetahuan yang baik tidak cukup dalam upaya memberantas jentik nyamuk penular DBD. Sikap dan tindakan PSN seperti menutup, menguras, dan mengubur bendabenda yang dapat menjadi genangan air tempat perkembangbiakan jentik nyamuk penular DBD yang baik perlu dilakukan secara mandiri, teratur dan berkesinambungan agar dapat mengurangi perkembangbiakan jentik nyamuk tersebut.

\section{SARAN}

Penelitian selanjutnya perlu dilakukan untuk meneliti faktor-faktor yang mempengaruhi perilaku masyakarat di Kecamatan Medan Marelan terhadap penyakit DBD dan penularannya. Hal ini penting agar masyarakat mengenali dan mengidentifikasi penyebab masih cukup tingginya kasus DBD di daerah tersebut.

Masyarakat juga perlu terus dibina melalui penyuluhan dan motivasi yang intensif mengenai DBD dan pencegahannya dengan perilaku yang benar dan tindakan pemberantasan sarang nyamuk yang berkelanjutan. Penting juga untuk menggalakkan lagi pelaksanaan programprogram dalam upaya penanggulangan DBD. Pemerintah setempat dalam hal ini Dinas Kesehatan dan Puskesmas perlu lebih intensif dalam kegiatan-kegiatan yang penting untuk pemberantasan sarang nyamuk, di antaranya kegiatan pemeriksaan jentik berkala, fogging dan semakin giat mendorong masyarakat melaksanakan kegiatan $3 \mathrm{M}$ plus secara mandiri dan teratur.

\section{UCAPAN TERIMA KASIH}

Ucapan terima kasih diberikan kepada Camat Medan Marelan yang telah mengizinkan untuk dilaksanakannya penelitian ini di area kerja beliau. Ucapan terima kasih juga peneliti haturkan kepada Lembaga Penelitian dan Pengabdian Masyarakat Universitas HKBP Nommensen yang telah mendukung dana untuk terlaksananya penelitian ini.

\section{DAFTAR PUSTAKA}

1. Kementerian Kesehatan RI. Demam Berdarah Dengue di Indonesia Tahun 1968-2009. Vol. 2, Buletin Jendela Epidemiologi. 2010.48 p.

2. Kementerian Kesehatan RI. Profil Kesehatan Indonesia 2017. Profil Kesehat Indones 2017. 
2018;100.

3. Back AT, Lundkvist A. Dengue viruses - an overview. Infect Ecol Epidemiol [Internet]. $2013 ; 3: 121$. Available from: http://www.pubmedcentral.nih.gov/articl erender.fcgi?artid=3759171\&tool=pmcent rez\&rendertype $=$ abstract

4. Sukohar A. Demam Berdarah Dengue (DBD). Medula [Internet]. 2014;2(2):115. A v a i l a b l e f $\mathrm{r}$ o m : http://juke.kedokteran.unila.ac.id/index.p $\mathrm{hp} / \mathrm{medula} /$ article/view/311/309

5. Koban AW. Kebijakan Pemberantasan Wabah Penyakit; KLB Demam Berdarah Dengue (KLB DBD). Indones Inst. 2010;(Bappenas 2005):135.

6. Utami RSB. Hubungan pengetahuan dan tindakan masyarakat dengan kejadian demam berdarah dengue (DBD) (studi di kelurahan putat jaya surabaya tahun 20102014).J Berk Epidemiol. 2015;3(2):24253.

7. Suyasa ING, Putra NA AI. Hubungan Faktor Lingkungan dan Perilaku Masyarakat dengan Keberadaan Vektor Demam Berdarah Dengue (DBD) di Wilayah Kerja Puskesmas I Denpasar Selatan. Ecotrophic [Internet]. 2010;3(1):16. Available from: file:///C:/Users/HP/Downloads/Hubunga n_Faktor_Lingkungan_dan_Perilaku_Masya rakat.pdf

8. Profil Kesehatan Kota Medan [Internet]. 20016 . A v a i l a b l e f r o m : http://www.depkes.go.id/resources/dow nload/profil/PROFIL_KAB_KOTA_2016/12 75_Sumut_Kota_Medan_2016.pdf

9. Tairas S, Posangi J, Kandou GD. Analisis Pelaksanaan Pengendalian Kabupaten Minahasa Utara Demam Berdarah Dengue di Analysis of Implementation of Control of Dengue Hemorrhagic Fever in North Minahasa Regency. JIKMU. 2015;5(1):219.
10. Zein U, Islam U, Utara S. Prinsip FarmakologiEndokrin-Infeksi-Pengobatan Berbasis Patobiologi. 1st ed. PT Sofmedia; 2018. $176206 \mathrm{p}$.

11. Joharina AS, Widiarti. Kepadatan Larva Nyamuk Vektor sebagai Indikator Penularan Demam Berdarah Dengue di Daerah Endemis di Jawa Timur. J Vektor Penyakit. 2014;8(2):3340.

12. Susmaneli H. Faktor-Faktor yang Berhubungan dengan Kejadian DBD di RSUD Kabupaten Rokan Hulu. J Kesehat Komunitas. 2011;1(5):14954.

13. Yudhastuti R, Vidiyani A. Hubungan Kondisi Lingkungan, Kontainer, Dan Perilaku Masyarakat Dengan Keberadaan Jentik Nyamuk Aedes Aegypti Di Daerah Endemis Demam Berdarah Dengue Surabaya. J Kesehat Lingkung. 2005;1(2):17083.

14. Fidayanto R, Susanto H, Yohanan A, Yudhastuti R. Model Pengendalian Demam Berdarah Dengue. J Kesehat Mayarakat. 2013;7(11):5228.

15. Hastuti NM, Dharmawan R, Indarto D. Sanitation-Related Behavior, Container Index , and Their Associations with Dengue Hemorrhagic Fever Incidence in Karanganyar , Central Java. J Epidemiol Public Heal. 2017;2(January):17485.

16. Pujiyanti A, Trapsilowati W. Pengetahuan, Sikap dan Perilaku Ibu Rumah Tangga dalam Pencegahan Demam Berdarah Dengue di Kelurahan Kutowinangun, Salatiga. J Vektora. 2010;2(2):10215.

17. Azlina A, Adrial, Anas E. Hubungan Tindakan Pemberantasan Sarang Nyamuk Dengan Keberadaan Larva vektor DBD di Kelurahan Lubuk Buaya. J Kesehat Andalas [Internet]. 2016 ; 5 (1):2217. Available from: http://jurnal.fk.unand.ac.id 